\title{
First Total Synthesis of N-4909 and Its Diastereomer; A Stimulant of Apolipoprotein E Secretion in Human Hepatoma Hep G2 Cells
}

\author{
Makoto YanaI* and Shigeru Hiramoto \\ 1st Pharmaceutical Laboratory, Pharmaceutical Research Laboratories, \\ Nisshin Flour Milling Co., Ltd., \\ 5-3-1 Tsurugaoka, Ohi-machi, Iruma-gun, Saitama 356-8511, Japan \\ ${ }^{\dagger}$ Research Laboratories, \\ Nisshin Kyorin Pharmaceutical Co., Ltd., \\ 5-3-1 Tsurugaoka, Ohi-machi, Iruma-gun, Saitama 356-8511, Japan
}

(Received for publication October 8, 1998)

\begin{abstract}
Both $(R)$ - and $(S)$-3-hydroxy-13-methyltetradecanoic acids were prepared via a lipasecatalyzed enantioselective acylation. The total synthesis of N-4909 and its diastereomer were achieved by a coupling of either $(R)$ - or $(S)$-3-hydroxy-13-methyltetradecanoic acid moiety with a hexapeptide moiety and by a cyclization with HATU $(O$-(7-azabenzotriazol1-yl)-1,1,3,3-tetramethyluronium hexafluorophosphate) and HOAt (1-hydroxy-7-azabenzotriazole) in a high dilution condition. The $R$ configuration of 3-hydroxy-13-methyltetradecanoic acid was found to be important for stimulating the activity of apolipoprotein $E$ secretion in human hepatoma Hep G2 cells.
\end{abstract}

N-4909 (1a), a stimulator of apolipoprotein E (apo E) secretion from human hepatoma Hep G2 cells, was isolated from the culture broth of Bacillus sp. No. 4691 by HiRamoto et al. ${ }^{1)}$ Apo E regulates plasma clearance of apolipoprotein B containing lipoproteins such as high density lipoprotein, intermediate density lipoprotein and low density lipoprotein (LDL). In Watanabe heritable hyperlipidemic rabbits, apo E prevented the progression of atherosclerosis. ${ }^{2)}$ In hyperlipidemic rabbits, plasma cholesterol levels were decreased markedly by intravenous injection. ${ }^{3,4)}$

The structure of this compound was determined as shown in Fig.1. This compound had been found to be an inhibitor of acyl-CoA: cholesterol acyltransferase. ${ }^{5)}$

In this paper, we report the first total synthesis of N-4909 and its diastereomer and also their effect on apo E secretion from Hep G2 cells.

\section{Chemistry}

The synthetic strategy for N-4909 and its diastereomer is outlined retrosynthetically in Scheme 1. The cyclization reaction between a carboxyl group of the hydroxy fatty acid and an $\alpha$-amino group of glutamine is conducted by the HATU-HOAt method in a high dilution condition.
The heptapeptide moiety of the cyclization precursor is constructed from the hexapeptide and the amino ester. The hexapeptide portion is synthesized by a conventional method. The Fmoc group is used for protection of the $\alpha$-amino function and later removed with diethylamine or piperidine. The carboxylic acid in the side chain of Asp is protected with tert-butyl ester and the carbamoyl in the side chain of Gln is protected with the Trt group. These protecting groups are removed by TFA after the ring formation. Each of the protected peptide fragments is prepared in a stepwise manner using the WSCI-HOBt method. The $C$-terminal of the fragments is protected with a benzyl ester which is removed before the

Fig. 1. Structure of N-4909.

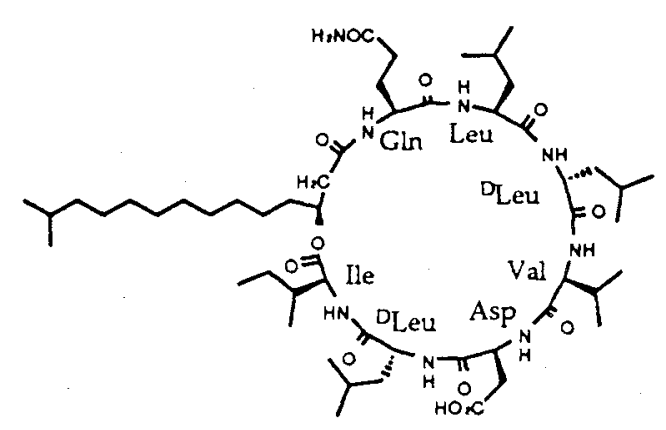


Scheme 1. Retrosynthetic analysis of N-4909 and its diastereoisomer.

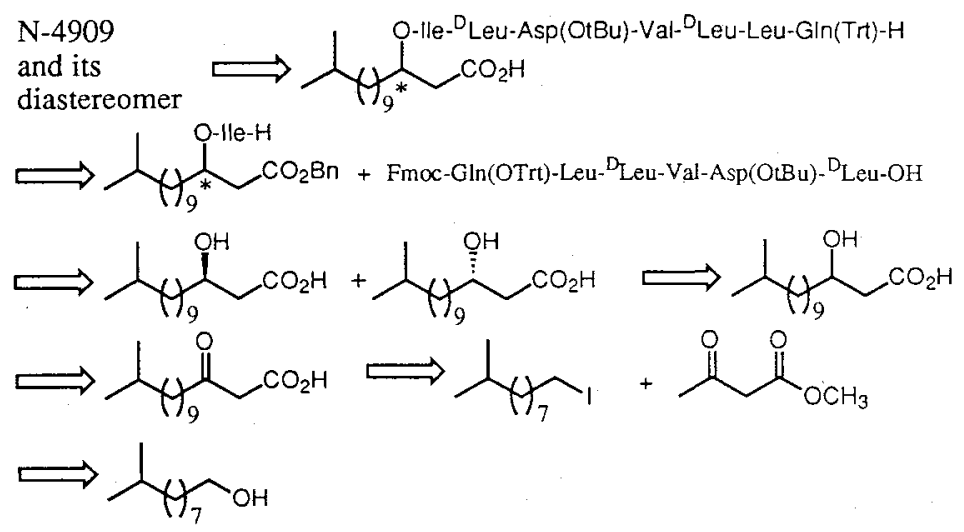

condensation.

The fatty acid $(R)$ - or $(S)$-3-hydroxy-13-methyltetradecanoic acid is prepared via a lipase-catalyzed enantioselective acylation. ${ }^{6)}$ The racemic $\beta$-hydroxy carboxylic acid is obtained from the $\beta$-ketoester which is prepared from a dianion of methyl acetacetate and an alkyl iodide. The alkyl iodide is synthesized from the corresponding alcohol.

First, we attempted to construct 9-methyldecanol (6) (Scheme 2). 9-Methyl-7-oxo-1-decanoic acid (4) was obtained from 3-methylbutanoyl chloride (2) and 1-morpholinocyclohexene (3). ${ }^{7}$ Wolff-Kishner reduction and lithium aluminum hydride reduction of this keto acid 4 gave the desired alcohol 6 in $41 \%$ yield from 2 . An alternative route to make this alcohol $\mathbf{6}$ was the following sequential reactions: the Wittig reaction of phosphonium salt of ethyl 6-bromocaproate (13) with isovaleraldehyde, lithium aluminum hydride reduction and hydrogenation.

Second, we attempted to make racemic $\beta$-hydroxy carboxylic acid (9). Methyl 13-methyl-3-oxo-tetradecanoate (8) was synthesized by the $\gamma$-alkylation of the dianion of methyl acetoacetate with 1-iodo-9-methyldecane (7) obtained from 6 with iodine, $\mathrm{PPh}_{3}$ and imidazole in tetrahydrofuran-hexamethylphosphoramide in $69 \%$ yield. ${ }^{8)}$ This compound $\mathbf{8}$ was converted to ( \pm )-3hydroxy-13-methyltetradecanoic acid (10) by sodium borohydride reduction and saponification.

Racemic $\beta$-hydroxy carboxylic acid $\mathbf{1 0}$ was treated with Pseudomonas lipase (lipase PS-30, Amano) in a mixture of vinyl acetate and THF in the presence of the polymerization inhibitor, di-t-butyl-p-cresol (BHT) at $65^{\circ} \mathrm{C}$ for 48 hours. (R)-3-Hydroxy-13-methyltetradecanoic acid (11) in a highly pure state $\left([\alpha]_{\mathrm{D}}-13.6^{\circ}\left(c 1.02, \mathrm{CHCl}_{3}\right)\right.$, $98 \%$ e.e.; determined by NMR spectrum of the $(R)$ - $(+)$-methyl- $\alpha$-(trifluoromethyl)phenylacetyl ester) was obtained in $37 \%$ yield after recrystallization from $n$-hexane. The $O$-acetyl group of the $\mathrm{S}$-rich acetylated product $\mathbf{1 2}$ was removed by alkaline hydrolysis. Fractional crystallization of the resulting S-rich hydroxy fatty acid $\mathbf{1 3}$ as $(S)-(-)-\alpha$-methylbenzyl amine (MBA) salt for three times gave the optically highly pure

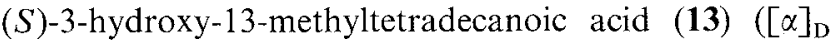
$+13.6^{\circ}\left(c 1.05, \mathrm{CHCl}_{3}\right), 93 \%$ e.e.; determined by NMR spectrum of the $(R)-(+)$-methyl- $\alpha$-(trifluoromethyl)phenylacetyl ester) in $29 \%$ yield from 10 .

To yield Fmoc-Asp(OtBu)-D-Leu-Obzl (17), Fmoc$\mathrm{Asp}(\mathrm{OtBu})-\mathrm{OH}$ was coupled quantitatively with $\mathrm{H}-\mathrm{D}-$ Leu-OBzl by the WSCI-HOBt method. A $\mathrm{CH}_{2} \mathrm{Cl}_{2}$ solution of Fmoc-Val-OH and H-Asp(OtBu)-D-LeuOBzl (18), obtained by deblocking the dipeptide 17 with diethylamine, was treated with WSCI-HOBt to give Fmoc-Val-Asp(OtBu)-D-Leu-OBzl (19) quantitatively. After deprotection with diethylamine in $69 \%$ yield, the tripeptide 20 was coupled with Fmoc-D-Leu-OH, isolated and then purified by the usual manner to yield the tetrapeptide 21 in $87 \%$ yield. The peptide 21 was converted to Fmoc-Leu-D-Leu-Val-Asp(OtBu)-D-LeuOBzl (22) by the deprotection of the peptide 21 with piperidine and the coupling with Fmoc-Leu-OH by the WSCI-HOBt method in $80 \%$ yield. The peptide $\mathbf{2 3}$ was deblocked with piperidine in $96 \%$ yield and then allowed to react with Fmoc-Gln(Trt)-OH to give Fmoc-Gln(Trt)Leu-D-Leu-Val-Asp(OtBu)-D-Leu-OBzl (25) in 95\% yield, which was hydrogenated to yield Fmoc-Gln(Trt)Leu-D-Leu-Val-Asp(OtBu)-D-Leu-OH (26) in $83 \%$ yield.

Optically active 13-methyl-( $S)$ or $(R)$-3-hydroxytetradecanoic acid (11 or 13) was converted to the corresponding benzyl ester 27 using benzyl bromide. 
Scheme 2. Synthesis of 13-methyl-(S)-3-hydroxytetradecanoic acid and its enantiomer.

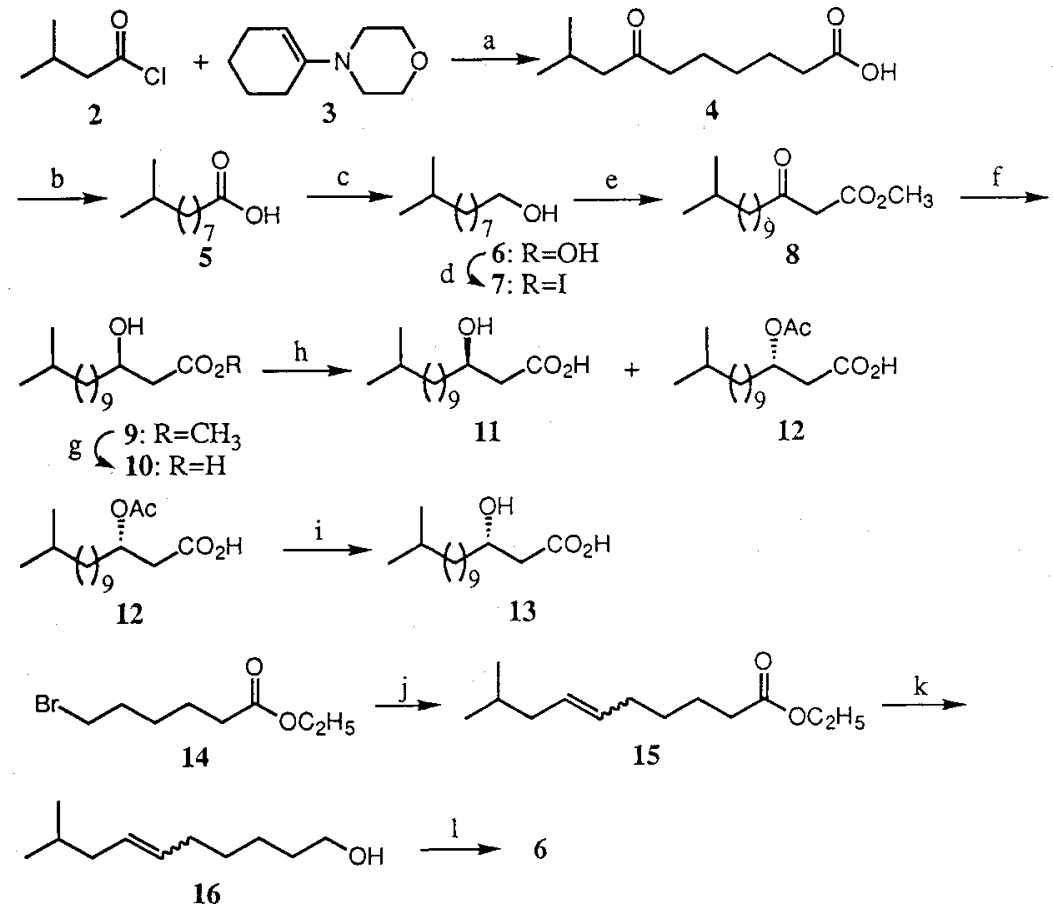

a: 1) TEA, 2) $20 \% \mathrm{HCl}$, b: $\mathrm{NaOH}, 76 \%$ for three steps, c: $\mathrm{LAH}, 74 \%$, d: imidazole, $\mathrm{PPh}_{3}$, $\mathrm{I}_{2}$, e: methyl acetoacetate, $\mathrm{NaH}, n$-BuLi/HMPA-THF, $69 \%$, f: $\mathrm{NaBH}_{4}, 73 \%$, g: $\mathrm{KOH} / \mathrm{MeOH}-\mathrm{H}_{2} \mathrm{O}, 82 \%$, h: Lipase PS-30, vinyl acetate, $65^{\circ} \mathrm{C}, 48$ hours, i: 1) $\mathrm{KOH} / \mathrm{MeOH}, 83 \%$, 2) (S)-(-)-1-phenylethylamine $/ \mathrm{CH}_{3} \mathrm{CN}$, recrystallization, three times, j: 1) $\mathrm{PPh}_{3} /$ toluene, 2) $\mathrm{NaH} / \mathrm{CH}_{3} \mathrm{CN},\left(\mathrm{CH}_{3}\right)_{2} \mathrm{CHCH}_{2} \mathrm{CHO}$, k: LAH, 81\% from 14, 1: 5\% Pd-C, $\mathrm{H}_{2}$.

Scheme 3. Synthesis of hexapeptide: Fmoc-Gln(Trt)-Leu-D-Leu-Val-Asp(OtBu)-D-Leu-OH.

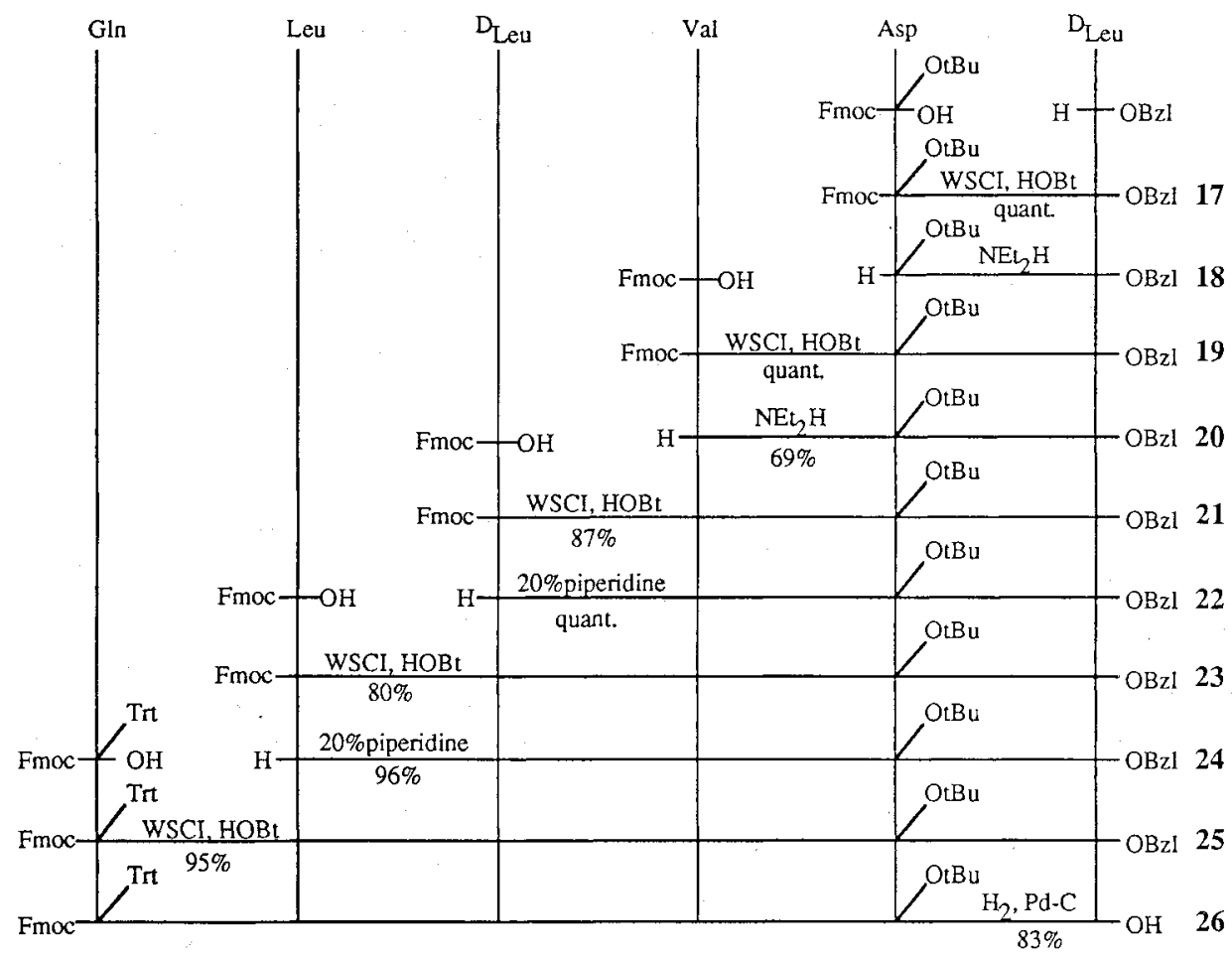


Scheme 4. Synthesis of N-4909 and its diastereomer.
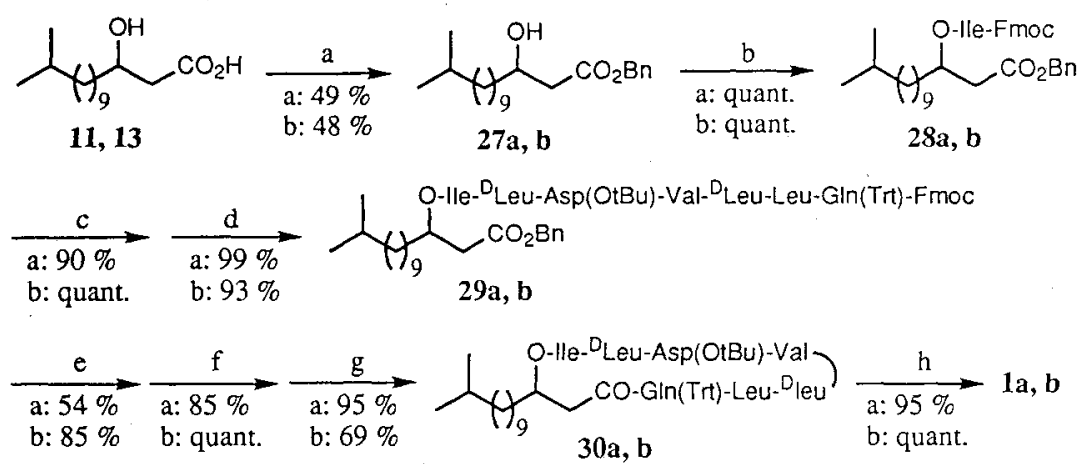

a: $\mathrm{PhCH}_{2} \mathrm{Br}, \mathrm{NEt}_{3}$, b: Fmoc-Ile, DCC, DMAP, c: $\mathrm{NEt}_{2} \mathrm{H}$, d: 26, WSCI, HOBt, e: $20 \%$ piperidine, f: $5 \%$ Pd-C, $\mathrm{H}_{2}$, g: HATU, HOAt, DIPEA, h: TFA

Table 1. Effects of N-4909 (1a) and its diastereomer $(\mathbf{1 b})$ on the secretion of apo E by Hep G2 cells. ( $\%$ of each control value)

\begin{tabular}{ccc}
\hline$(\mu \mathrm{M})$ & N-4909 (1a) & Its diastereomer $(\mathbf{1 b})$ \\
\hline 1.0 & 273 & 259 \\
5.0 & 471 & 381 \\
\hline
\end{tabular}

Benzyl 13-methyl-( $R$ ) or (S)-3-(Fmoc-Ile-O)-tetradecanoate (28) was obtained by the coupling between Fmoc-Ile-OH and benzyl 13-methyl- $(R)$ or $(S)$-3-hydroxytetradecanoic acid (27) with DCC and DMAP. The $N^{\alpha}$-deprotected product of the ester (28) was coupled with Fmoc-Gln(Trt)-Leu-D-Leu-Val-Asp(OtBu)D-Leu-OH (26) by the WSCI-HOBt method to yield benzyl 13-methyl- $(R)$ or $(S)$-3-(Fmoc-Gln(Trt)-Leu-DLeu-Val-Asp(OtBu)-D-Leu-O)-tetradecanoate (29). Then the Fmoc group and the benzyl group were deprotected in the usual manner. Cyclization was achieved by a high dilution method in DMF with HATU and HOAt at room temperature. The protected cyclization product, cyclo\{13-methyl- $(R)$ or $(S)$-3-[Gln(Trt)-Leu-D-Leu-Val-Asp(OtBu)-D-Leu-O]-tetradecanoate (30), was obtained. The removal of the protecting group by TFA gave the product, $\mathrm{N}-4909$ (1a) or its diastereomer (1) $)$.

\section{Results and Discussion}

Table 1 shows the secreted level of apo E from Hep G2 cells with N-4909 (1a) and its diastereomer (1b). These results show that the effects of both enantiomer at $1.0 \mu \mathrm{M}$ level are almost the same, but at a higher dose $(5.0 \mu \mathrm{M})$ 1a has a stronger effect than $\mathbf{1 b}$. Therefore, the $(R)$ configuration of 3-hydroxy-13-methyltetradecanoic acid is important for showing the stronger effect on the secretion of apo E by Hep G2 cells. The effect of this configuration on other lipoproteins is now under investigation.

\section{Experimental}

\section{General}

Melting points were determined on a micto melting point apparatus and were uncorrected. Optical rotations were obtained on a JASCO DIP-370 digital polarimeter. ${ }^{1} \mathrm{H}$ NMR spectra were recorded at $400 \mathrm{MHz}$ on a JEOL JNM-EX400 spectrometer. ESI-MS spectra were obtained on a Micromass Quattro II instrument.

\section{Biological Activity}

Effects of N-4909 (1a) and its diastereomer (1b) on the secretion of apolipoprotein E by Hep G2 cells were measured by the procedure described in the previous paper. ${ }^{1)}$

\section{Reagents}

Unless otherwise stated, all reagents and solvents were obtained commercially as reagent grade products and used without further purification.

\section{Peptide Synthesis}

The $\alpha$-amino function of amino acids was protected by the Fmoc group. The $\beta$-carboxyl group of Asp was protected by the tert-Bu group. The carbamoyl group of 
Gln was protected by the Trt group. The protecting group for fatty acids was Bzl for the carboxyl group.

\section{9-Methy-7-oxo-1-decanoic acid (4)}

To a solution of 1-morpholinocyclohexene (3) (25.0 g, $149 \mathrm{mmol})$ and triethylamine $(15.1 \mathrm{~g}, 149 \mathrm{mmol})$ in $\mathrm{CHCl}_{3}(75 \mathrm{ml})$ under $\mathrm{Ar}$ was added a solution of 3-methylbutanoyl chloride (2) $(18.0 \mathrm{~g}, 149 \mathrm{mmol})$ in $\mathrm{CHCl}_{3}(30 \mathrm{ml})$ at an ice cooled temperature over a period of 30 minutes. This reaction mixture was stirred at room temperature overnight. Then, $20 \%$ aq. $\mathrm{HCl}(75 \mathrm{ml})$ was added and the mixture was refluxed for 5 hours and cooled to room temperature. The separated $\mathrm{CHCl}_{3}$ layer was rinsed with brine and dried over anhydrous $\mathrm{Na}_{2} \mathrm{SO}_{4}$. After removal of the solvent, the residure was refluxed in $\mathrm{H}_{2} \mathrm{O}(30 \mathrm{ml})$ containing $\mathrm{NaOH}(18 \mathrm{~g}, 0.45 \mathrm{~mol})$ for 1 hour. The resultant mixture was poured into ice water $(150 \mathrm{ml})$ and extracted with $\mathrm{CHCl}_{3}(2 \times 75 \mathrm{ml})$. The combined organic layers were rinsed with brine and dried $\left(\mathrm{Na}_{2} \mathrm{SO}_{4}\right)$. After removal of the solvent, the crude product was purified by chromatography on silica gel $(150 \mathrm{~g})$, eluting with $n$-Hex : AcOEt $=4: 1$, to yield the product $(22.7 \mathrm{~g}, 76 \%)$.

${ }^{1} \mathrm{H} \mathrm{NMR}\left(400 \mathrm{MHz}, \mathrm{CDCl}_{3}\right) \delta 10.4(1 \mathrm{H}, \mathrm{brs}, \mathrm{COO} H)$, $2.39\left(2 \mathrm{H}, \mathrm{t}, J=7.3 \mathrm{~Hz}, \mathrm{COCH}_{2}\right), 2.36(2 \mathrm{H}, \mathrm{t}, J=7.6 \mathrm{~Hz}$, $\left.\mathrm{CH}_{2} \mathrm{CO}_{2} \mathrm{H}\right), 2.27\left(2 \mathrm{H}, \mathrm{d}, J=6.8 \mathrm{~Hz}, \mathrm{CHCH}_{2}\right), 2.08 \sim 2.16$ $\left(1 \mathrm{H}, \mathrm{m}, \mathrm{CH}\left(\mathrm{CH}_{3}\right)_{2}\right), 1.64(2 \mathrm{H}$, quint., $J=7.3 \mathrm{~Hz}$, $\mathrm{CH}_{2} \mathrm{CH}_{2} \mathrm{CH}_{2}$ ), 1.59 (2H, quint., $J=7.2 \mathrm{~Hz}, \mathrm{CH}_{2} \mathrm{CH}_{2}-$ $\left.\mathrm{CH}_{2}\right), 1.30 \sim 1.38\left(2 \mathrm{H}, \mathrm{m}, \mathrm{CH}_{2} \mathrm{CH}_{2} \mathrm{CH}_{2}\right), 0.91(6 \mathrm{H}, \mathrm{d}$, $\left.J=6.8 \mathrm{~Hz}, \mathrm{CH}\left(\mathrm{CH}_{3}\right)_{2}\right)$.

\section{9-Methyl-1-decanoic Acid (5)}

A mixture of $4(11.8 \mathrm{~g}, 58.9 \mathrm{mmol}), \mathrm{N}_{2} \mathrm{H}_{4} \cdot \mathrm{H}_{2} \mathrm{O}$ $(20.2 \mathrm{ml}), \mathrm{KOH}(3.31 \mathrm{~g}, 58.9 \mathrm{mmol})$ and diethylene glycol $(60 \mathrm{ml})$ was refluxed for 8 hours. After cooling to room temperature, $\mathrm{KOH}(1.65 \mathrm{~g}, 29.5 \mathrm{mmol}, 0.5 \mathrm{eq})$ and diethylene glycol $(60 \mathrm{ml})$ were added to the mixture. This reaction mixture was refluxed for 15 hours and then poured into ice cooled water ( 1.6 liter). The resultant mixture was acidified with conc. $\mathrm{HCl}$ to $\mathrm{pH} 3$ and cooled with an ice bath. The crystalline solid was collected, dissolved in $\mathrm{CHCl}_{3}$ and then dried $\left(\mathrm{MgSO}_{4}\right)$. After removal of the solvent, the crude product was purified by chromatography on silica gel $(60 \mathrm{~g})$, eluting with $\mathrm{CHCl}_{3}$, to yield the product $(5.04 \mathrm{~g}, 46 \%)$.

${ }^{1} \mathrm{H} \mathrm{NMR}\left(400 \mathrm{MHz}_{2} \mathrm{CDCl}_{3}\right) \delta 9.00(1 \mathrm{H}$, br s, $\mathrm{COOH})$, $2.35\left(2 \mathrm{H}, \mathrm{t}, J=7.6 \mathrm{~Hz}, \mathrm{CH}_{2} \mathrm{CO}_{2} H\right), 1.63$ (2H, quint., $\left.J=7.1 \mathrm{~Hz}, \mathrm{CH}_{2} \mathrm{CH}_{2} \mathrm{CO}_{2} \mathrm{H}\right), 1.52(1 \mathrm{H}$, sept., $J=6.7 \mathrm{~Hz}$, $\left.\mathrm{CH}\left(\mathrm{CH}_{3}\right)_{2}\right), 1.22 \sim 1.37\left(8 \mathrm{H}, \mathrm{m}, \mathrm{CH}_{2}\right), 1.11 \sim 1.17(2 \mathrm{H}$, $\left.\mathrm{m}, \mathrm{C} \mathrm{H}_{2}\right), 0.86\left(6 \mathrm{H}, \mathrm{d}, J=6.8 \mathrm{~Hz}, \mathrm{CH}\left(\mathrm{CH}_{3}\right)_{2}\right)$.
9-Methyl-1-decanol (6)

To a suspension of LAH $(0.60 \mathrm{~g}, 16 \mathrm{mmol})$ in $\mathrm{Et}_{2} \mathrm{O}$ $(40 \mathrm{ml})$ was added a solution of $5(3.70 \mathrm{~g}, 19.9 \mathrm{mmol})$ in $\mathrm{Et}_{2} \mathrm{O}(30 \mathrm{ml})$ over a period of 30 minutes. After refluxing for 30 minutes, this was cooled to room temperature. To this was added $\mathrm{H}_{2} \mathrm{O}(0.6 \mathrm{ml}), 15 \%$ aq. $\mathrm{NaOH}$ and $\mathrm{H}_{2} \mathrm{O}$ $(1.8 \mathrm{ml})$. The ether layer was dried $\left(\mathrm{Na}_{2} \mathrm{SO}_{4}\right)$. After removal of the solvent, the crude product was purified by chromatography on silica gel $(40 \mathrm{~g})$, eluting with $n$-Hex : AcOEt $=4: 1$, to yield the product $(2.53 \mathrm{~g}, 74 \%)$.

${ }^{1} \mathrm{H} \mathrm{NMR}\left(400 \mathrm{MHz}, \mathrm{CDCl}_{3}\right) \delta 3.64(2 \mathrm{H}, \mathrm{t}, J=6.6 \mathrm{~Hz}$, $\left.\mathrm{CH}_{2} \mathrm{OH}\right), 1.45 \sim 1.61\left(3 \mathrm{H}, \mathrm{m}, \mathrm{CH}_{2} \mathrm{H}_{2} \mathrm{OH}+\mathrm{CH}\left(\mathrm{CH}_{3}\right)_{2}\right)$, $1.20 \sim 1.40\left(11 \mathrm{H}, \mathrm{m}, \mathrm{CH}_{2}+\mathrm{CH}_{2} \mathrm{OH}\right), 1.10 \sim 1.20(2 \mathrm{H}$, $\left.\mathrm{m}, \mathrm{CH}_{2}\right), 0.86\left(6 \mathrm{H}, \mathrm{d}, J=6.8 \mathrm{~Hz}, \mathrm{CH}\left(\mathrm{CH}_{3}\right)_{2}\right)$.

\section{1-Iodo-9-methyldecane (7)}

To a solution of 6 of benzene ( 1.5 liters) were added imidazole ( $28.6 \mathrm{~g}, 0.42 \mathrm{~mol}, 2.5 \mathrm{eq}$ ), triphenylphosphine (110 g, $0.42 \mathrm{~mol}, 2.5 \mathrm{eq})$ and iodine $(85 \mathrm{~g}, 0.34 \mathrm{~mol}, 2 \mathrm{eq})$ at room temperature. This reaction mixture was stirred at room temperature for 3 hours and then rinsed with sat. aq. $\mathrm{Na}_{2} \mathrm{SO}_{4}$ and brine, and then dried $\left(\mathrm{MgSO}_{4}\right)$. After removal of the solvent at a bath temperature below $30^{\circ} \mathrm{C}$, the formed crystals were filtered off. After removal of the solvent at a bath temperature below $30^{\circ} \mathrm{C}$, the crude product was purified by chromatography on silica gel $(200 \mathrm{~g})$, eluting with $n$-Hex, to yield the product $(36.1 \mathrm{~g}, 76 \%)$.

${ }^{1} \mathrm{H} \mathrm{NMR}\left(400 \mathrm{MHz}, \mathrm{CDCl}_{3}\right) \delta 3.19(2 \mathrm{H}, \mathrm{t}, J=6.8 \mathrm{~Hz}$, $\mathrm{CH}_{2} \mathrm{I}$ ), 1.82 (2H, quint., $\left.J=7.2 \mathrm{~Hz}, \mathrm{CH}_{2} \mathrm{CH}_{2} \mathrm{I}\right), 1.46 \sim$ $1.56\left(1 \mathrm{H}, \mathrm{m}, \mathrm{CH}\left(\mathrm{CH}_{3}\right)_{2}\right), 1.20 \sim 1.40\left(10 \mathrm{H}, \mathrm{m}, \mathrm{CH}_{2}\right)$, $1.10 \sim 1.20\left(2 \mathrm{H}, \mathrm{m}, \mathrm{CH}_{2}\right), 0.86(6 \mathrm{H}, \mathrm{d}, J=6.3 \mathrm{~Hz}$, $\left.\mathrm{CH}\left(\mathrm{CH}_{3}\right)_{2}\right)$.

\section{Methyl 3-Oxo-13-methyltetradecanoate (8)}

To a suspension of $\mathrm{NaH}(60 \%, 12.8 \mathrm{~g}, 0.32 \mathrm{~mol}, 2.5 \mathrm{eq})$ in THF $(720 \mathrm{ml})$ and HMPA $(86 \mathrm{ml})$ was added dropwise methyl acetoacetate $(27.6 \mathrm{ml}, 0.26 \mathrm{ml}, 2.0 \mathrm{eq})$ at an ice cooled temperature. After stirring at $5^{\circ} \mathrm{C}$ for 10 minutes, $n$-BuLi in hexane $(1.57 \mathrm{M}, 178 \mathrm{ml}, 0.28 \mathrm{~mol}, 2.2 \mathrm{eq})$ was added dropwise to this and stirred at $5^{\circ} \mathrm{C}$ for 10 minutes. To this added a solution of $7(36.1 \mathrm{~g}, 0.13 \mathrm{~mol})$ in $\mathrm{THF}$ $(100 \mathrm{ml})$. This reaction mixture was stirred at room temperature for 1 hour and sat. aq. $\mathrm{NH}_{4} \mathrm{Cl}$ was added to this. $1 \mathrm{M} \mathrm{HCl} \mathrm{aq} \mathrm{was} \mathrm{added} \mathrm{to} \mathrm{this} \mathrm{solution} \mathrm{to} \mathrm{pH} 2$ and extracted with $\mathrm{Et}_{2} \mathrm{O}$. The combined organic layers were dried $\left(\mathrm{Na}_{2} \mathrm{SO}_{4}\right)$. After removal of the solvent, the crude product was purified by chromatography on silica gel $(300 \mathrm{~g})$, eluting with $n$-Hex: AcOEt $=400: 0 \sim 20$, to yield the product $(23.8 \mathrm{~g}, 69 \%)$. 
${ }^{1} \mathrm{H} \mathrm{NMR}\left(400 \mathrm{MHz}, \mathrm{CDCl}_{3}\right) \delta 3.74\left(3 \mathrm{H}, \mathrm{s}, \mathrm{CO}_{2} \mathrm{CH}_{3}\right)$, $3.45\left(2 \mathrm{H}, \mathrm{s}, \mathrm{COCH}_{2} \mathrm{CO}_{2} \mathrm{H}\right), 2.53(2 \mathrm{H}, \mathrm{t}, J=7.6 \mathrm{~Hz}$, $\left.\mathrm{CH}_{2} \mathrm{CO}\right), 1.55 \sim 1.63\left(2 \mathrm{H}, \mathrm{m}, \mathrm{CH}_{2} \mathrm{CH}_{2} \mathrm{CO}\right), 1.46 \sim 1.55$ $\left(1 \mathrm{H}, \mathrm{m}, \mathrm{CH}\left(\mathrm{CH}_{3}\right)_{2}\right), \quad 1.20 \sim 1.35\left(12 \mathrm{H}, \mathrm{m}, \mathrm{CH}_{2}\right)$, $1.10 \sim 1.20\left(2 \mathrm{H}, \mathrm{m}, \mathrm{CH}_{2}\right), 0.86(6 \mathrm{H}, \mathrm{d}, J=6.8 \mathrm{~Hz}$, $\left.\mathrm{CH}\left(\mathrm{CH}_{3}\right)_{2}\right)$.

Methyl 3-Hydroxy-13-methyltetradecanoate (9)

To a solution of $\mathrm{NaBH}_{4}(16.0 \mathrm{~g}, 0.42 \mathrm{~mol}, 4.8 \mathrm{eq})$ in $\mathrm{MeOH}(300 \mathrm{ml})$ was added a solution of $8(23.8 \mathrm{~g}$, $88 \mathrm{mmol})$ in $\mathrm{MeOH}(100 \mathrm{ml})$ dropwise at $-25 \sim-30^{\circ} \mathrm{C}$. This was stirred at this temperature for 2 hours and acidified to $\mathrm{pH} 2$ with $1 \mathrm{~N}$ aq. $\mathrm{HCl}$. This was extracted with $\mathrm{AcOEt}$ and the combined organic layers were rinsed with sat. aq. $\mathrm{NaHCO}_{3}$ and brine, and then dried $\left(\mathrm{Na}_{2} \mathrm{SO}_{4}\right)$. After removal of the solvent, the crude product was purified by chromatography on silica gel $(200 \mathrm{~g})$, eluting with $n$-Hex : AcOEt $=200: 0 \sim 60$, to yield the product $(17.4 \mathrm{~g}, 73 \%)$.

${ }^{1} \mathrm{H}$ NMR $\left(400 \mathrm{MHz}, \mathrm{CDCl}_{3}\right) \delta 3.97 \sim 4.03(1 \mathrm{H}, \mathrm{m}$, $\mathrm{CHOH}), 3.72\left(3 \mathrm{H}, \mathrm{s}, \mathrm{CO}_{2} \mathrm{CH}_{3}\right), 2.86(1 \mathrm{H}, \mathrm{d}, J=3.9 \mathrm{~Hz}$, $\mathrm{CHOH}), 2.52\left(1 \mathrm{H}, \mathrm{dd}, J=3.2,17 \mathrm{~Hz}, \mathrm{CH}_{2} \mathrm{CO}_{2} \mathrm{CH}_{3}\right)$, $2.41\left(1 \mathrm{H}, \mathrm{dd}, J=9.0,17 \mathrm{~Hz}, \mathrm{CH}_{2} \mathrm{CO}_{2} \mathrm{CH}_{3}\right), 1.35 \sim 1.60$ $\left(4 \mathrm{H}, \mathrm{m}, \mathrm{CH}_{2}\right), 1.20 \sim 1.35\left(13 \mathrm{H}, \mathrm{m}, \mathrm{CH}_{2}\right), 1.10 \sim 1.20$ $\left(2 \mathrm{H}, \mathrm{m}, \mathrm{CH} \mathrm{C}_{2}\right), 0.86\left(6 \mathrm{H}, \mathrm{d}, J=6.4 \mathrm{~Hz}, \mathrm{CH}\left(\mathrm{CH}_{3}\right)_{2}\right)$.

\section{(土)-3-Hydroxy-13-methyltetradecanoic Acid (10)}

A solution of $9(6.94 \mathrm{~g}, 25.5 \mathrm{mmol})$ in $1.3 \mathrm{M} \mathrm{KOH}$ $\left(130 \mathrm{ml}, \mathrm{MeOH}: \mathrm{H}_{2} \mathrm{O}=4: 1\right)$ was stirred at room temperature overnight. This was acidified with dilute $\mathrm{HCl}$ to $\mathrm{pH} \mathrm{l}$ and saturated with $\mathrm{NaCl}$. This was extracted with AcOEt and the combined organic layers were rinsed with brine and dried $\left(\mathrm{Na}_{2} \mathrm{SO}_{4}\right)$. After removal of the solvent, the crude product was purified by recrystallization from $n$-Hexane to yield the product $(5.40 \mathrm{~g}, 82 \%)$.

${ }^{1} \mathrm{H}$ NMR $\left(400 \mathrm{MHz}, \mathrm{CDCl}_{3}\right) \delta 3.99 \sim 4.07(1 \mathrm{H}, \mathrm{m}$, $\mathrm{C} H \mathrm{OH}), 2.58\left(1 \mathrm{H}, \mathrm{dd}, J=3.4,17 \mathrm{~Hz}, \mathrm{CH}_{2} \mathrm{CO}_{2} \mathrm{CH}_{3}\right)$, $2.47\left(1 \mathrm{H}, \mathrm{dd}, J=8.8,17 \mathrm{~Hz}, \mathrm{CH}_{2} \mathrm{CO}_{2} \mathrm{CH}_{3}\right), 1.39 \sim 1.60$ $\left(4 \mathrm{H}, \mathrm{m}, \mathrm{CH}_{2}\right), 1.19 \sim 1.39\left(13 \mathrm{H}, \mathrm{m}, \mathrm{CH}_{2}\right), 1.09 \sim 1.19$ $\left(2 \mathrm{H}, \mathrm{m}, \mathrm{CH}_{2}\right), 0.86\left(6 \mathrm{H}, \mathrm{d}, J=6.3 \mathrm{~Hz}, \mathrm{CH}\left(\mathrm{CH}_{3}\right)_{2}\right)$.

\section{(R)-3-Hydroxy-13-methyltetradecanoic Acid (11)}

To a solution of $10(15.0 \mathrm{~g}, 58.0 \mathrm{mmol})$ and BHT $(140 \mathrm{mg})$ in a mixture of vinyl acetate $(140 \mathrm{ml})$ and THF $(140 \mathrm{ml})$ was added lipase PS-30 $(9.3 \mathrm{~g})$. This reaction mixture was stirred at $65^{\circ} \mathrm{C}$ for 48 hours under the slow stream of $\mathrm{N}_{2}$ gas. After filtration and evaporation of the solvent, the crude product was purified by chromatography on silica gel $(100 \mathrm{~g})$, eluting with $\mathrm{CHCl}_{3}$ : $\mathrm{MeOH}=200: 0 \sim 30$, to yield the acetate $12(10.3 \mathrm{~g}, 59 \%)$ and the product $\mathbf{1 1}$ which was recrystallized from $n$-hexane $(5.49 \mathrm{~g}, 37 \%)$. MP $46.5 \sim 47.0^{\circ} \mathrm{C}$. $[\alpha]_{\mathrm{D}}^{25}-13.6^{\circ}$ (c $1.02, \mathrm{CHCl}_{3}$ ).

NMR spectrum of $\mathbf{1 1}$ was identical with that of $\mathbf{1 0}$. This was treated with diazomethane, subsequently by $(S)$-MTPA-Cl in pyridine to give $(S)$-MTPA ester.

\section{(S)-3-Hydroxy-13-methyltetradecanoic Acid (13)}

To a solution of $12(10.3 \mathrm{~g}, 34.2 \mathrm{mmol})$ in methanol $(60 \mathrm{ml})$ was added slowly a solution of $\mathrm{KOH}(3.84 \mathrm{~g}$, $58.2 \mathrm{mmol}, 1.7 \mathrm{eq})$ in methanol $(57 \mathrm{ml})$ at an ice cooled tempetarure. After stirred at room temperature overnight this was poured into ice cooled water $(400 \mathrm{ml})$. This was acidified to $\mathrm{pH} 4$ with dilute aq. $\mathrm{HCl}$ and extracted with AcOEt. The combined organic layers were rinsed with $\mathrm{H}_{2} \mathrm{O}$ and dried $\left(\mathrm{MgSO}_{4}\right)$. After removal of the solvent, the crude product was purified by recrystallization from $n$-hexane to yield the product $(7.37 \mathrm{~g}, 83 \%)$. This was crystallized as $(S)-(-)-1$-phenylethylamine salt in $\mathrm{CH}_{3} \mathrm{CN}$ three times. Treatment with $10 \%$ aq. citric acid and recrystallization from $n$-hexane gave $13-(4.31 \mathrm{~g}, 29 \%$ from 10). MP $47.0^{\circ} \mathrm{C} .[\alpha]_{\mathrm{D}}^{25}+13.6^{\circ}\left(c 1.05, \mathrm{CHCl}_{3}\right)$.

NMR spectrum of $\mathbf{1 3}$ was identical with that of $\mathbf{1 0}$. This was treated with diazomethane, subsequently by $(S)$-MTPA-Cl in pyridine to give $(S)$-MTPA ester.

\section{Ethyl 9-Methyl-6-decenoate (14)}

A solution of ethyl 6-bromocaproate (13) $(50 \mathrm{~g}$, $0.22 \mathrm{~mol})$ and triphenylphosphine $(61.7 \mathrm{~g}, 0.24 \mathrm{~mol})$ in toluene $(200 \mathrm{ml})$ was refluxed for 16 hours. After removal of the solvent, the residue was dissolved in acetonitrile $(200 \mathrm{ml})$ and isovaleraldehyde $(24 \mathrm{ml}, 0.22 \mathrm{~mol})$ was added at room temperature. $\mathrm{NaH}(60 \%, 9.0 \mathrm{~g}, 0.22 \mathrm{~mol})$ was added little by little to keep the reaction temperature within $25 \sim 35^{\circ} \mathrm{C}$. After addition, the reaction mixture was stirred at room temperature for 3 days. After addition of water $(110 \mathrm{ml})$, this was extracted with $n$-hexane three times. The combined organic layers were rinsed with water and dried $\left(\mathrm{MgSO}_{4}\right)$. After removal of the solvent, the crude product was cooled by an ice bath. The formed crystals were filtered off and the filtrate was concentrated to obtain the product which was used in the next reaction without further purification.

${ }^{1} \mathrm{H}$ NMR $\left(400 \mathrm{MHz}, \mathrm{CDCl}_{3}\right) \delta 5.34 \sim 5.42(2 \mathrm{H}, \mathrm{m}$, $\mathrm{C} H=\mathrm{CH}), 4.12\left(2 \mathrm{H}, \mathrm{q}, J=7.2 \mathrm{~Hz}, \mathrm{COCH}_{2} \mathrm{CH}_{3}\right), 2.30$ $\left(2 \mathrm{H}, \mathrm{t}, J=7.6 \mathrm{~Hz}, \mathrm{CH}_{2} \mathrm{CO}\right), 2.04(2 \mathrm{H}, \mathrm{q}, J=6.7 \mathrm{~Hz}$, $\left.\mathrm{CHCH}_{2} \mathrm{CH}_{2}\right), 1.91\left(2 \mathrm{H}, \mathrm{t}, J=6.1 \mathrm{~Hz}, \mathrm{CHCH}_{2} \mathrm{CH}\right)$, $1.55 \sim 1.68\left(3 \mathrm{H}, \mathrm{m}, \mathrm{CH}_{2}+\mathrm{CH}\left(\mathrm{CH}_{3}\right)_{2}\right), 1.34 \sim 1.42(2 \mathrm{H}$, $\left.\mathrm{m}, \mathrm{CH}_{2}\right), 1.25\left(3 \mathrm{H}, \mathrm{t}, J=7.3 \mathrm{~Hz}, \mathrm{CH}_{2} \mathrm{CH}_{3}\right), 0.89(6 \mathrm{H}, \mathrm{d}$, $\left.J=6.4 \mathrm{~Hz}, \mathrm{CH}\left(\mathrm{CH}_{3}\right)_{2}\right)$. 
9-Methyl-6-decen-1-ol (15)

To a solution of LAH $(4.25 \mathrm{~g}, 0.11 \mathrm{~mol})$ in $\mathrm{Et}_{2} \mathrm{O}$ $(420 \mathrm{ml})$ was added dropwise 14 at an ice-cooled temperature. After addition, this reaction mixture was stirred at room temperature for 4 hours. Then, water $(4.3 \mathrm{ml}), 15 \%$ aq. $\mathrm{NaOH}(4.3 \mathrm{ml})$ and water $(13 \mathrm{ml})$ were added dropwise and then dried $\left(\mathrm{Na}_{2} \mathrm{SO}_{4}\right)$. After removal of the solvent, the crude product was purified by chromatography on silica gel $(200 \mathrm{~g})$, eluting with $n$-Hex : AcOEt $=400: 0 \sim 60$, to yield the product $(30.8 \mathrm{~g}$, $81 \%$ ).

${ }^{1} \mathrm{H}$ NMR $\left(400 \mathrm{MHz}, \mathrm{CDCl}_{3}\right) \delta 5.34 \sim 5.44(2 \mathrm{H}, \mathrm{m}$, $\mathrm{C} H=\mathrm{CH}), 3.64\left(2 \mathrm{H}, \mathrm{t}, J=6.6 \mathrm{~Hz}, \mathrm{CH}_{2} \mathrm{OH}\right), 2.00 \sim$ $2.10\left(2 \mathrm{H}, \mathrm{m}, \mathrm{CHCH}_{2} \mathrm{CH}_{2}\right), 1.91(2 \mathrm{H}, \mathrm{t}, J=6.4 \mathrm{~Hz}$, $\left.\mathrm{CHCH}_{2} \mathrm{CH}\right), 1.52 \sim 1.61\left(3 \mathrm{H}, \mathrm{m}, \mathrm{CH} \mathrm{H}_{2}+\mathrm{CH}\left(\mathrm{CH}_{3}\right)_{2}\right)$, $1.30 \sim 1.42\left(5 \mathrm{H}, \quad \mathrm{m}, \mathrm{CH}_{2}+\mathrm{CH}_{2} \mathrm{OH}\right), 0.89(6 \mathrm{H}, \mathrm{d}$, $\left.J=6.8 \mathrm{~Hz}, \mathrm{CH}\left(\mathrm{CH}_{3}\right)_{2}\right)$.

\section{9-Methyl-1-decanol (6)}

A suspension of $15(30.8 \mathrm{~g}, 0.18 \mathrm{~mol})$ and $5 \% \mathrm{Pd}-\mathrm{C}$ $(2.00 \mathrm{~g})$ in methanol $(140 \mathrm{ml})$ was reacted at room temperature under a $\mathrm{H}_{2}$ atmosphere $\left(\sim 2 \mathrm{~kg} / \mathrm{cm}^{2}\right)$ for 3 hours. Filtration and removal of the solvent gave 6 quantitatively.

\section{Fmoc-Asp(OtBu)-D-Leu-OBzl (17)}

To a solution of Fmoc-D-Leu-OBzl $(9.00 \mathrm{~g}, 20 \mathrm{mmol})$ in $\mathrm{DMF}(200 \mathrm{ml})$ was added $\mathrm{NEt}_{2} \mathrm{H}(20 \mathrm{ml})$ and the solution was stirred at room temperature for 5 hours. Removal of the solvent gave the crude product which was used in the next reaction without further purification.

To a solution of this amine $(20 \mathrm{mmol})$, Fmoc$\mathrm{Asp}(\mathrm{OtBu})(9.05 \mathrm{~g}, 22 \mathrm{mmol}, 1.1 \mathrm{eq})$ and $\mathrm{HOBt} \cdot \mathrm{H}_{2} \mathrm{O}$ $(3.37 \mathrm{~g}, 22 \mathrm{mmol}, 1.1 \mathrm{eq})$ in $\mathrm{CH}_{2} \mathrm{Cl}_{2}(80 \mathrm{ml})$ was added $\mathrm{WSCI} \cdot \mathrm{HCl}(4.22 \mathrm{~g}, 22 \mathrm{mmol}, 1.1 \mathrm{eq})$ at an ice cooled temperature. This reaction mixture was stirred at this temperature for 2 hours and then at room temperature overnight. After removal of solvent, the residue was taken up to AcOEt and $10 \%$ aq. citric acid. The separated organic layer was rinsed with $\mathrm{H}_{2} \mathrm{O}, 5 \%$ aq. $\mathrm{NaHCO}_{3}$ and $\mathrm{H}_{2} \mathrm{O}$, and then dried $\left(\mathrm{Na}_{2} \mathrm{SO}_{4}\right)$. After removal of the solvent, the crude product was purified by recrystallization from Hex.-AcOEt to yield the product $(8.36 \mathrm{~g}, 68 \%)$. MP $102 \sim 102.5^{\circ} \mathrm{C}$. ESI-MS $\mathrm{m} / \mathrm{z} 615$ $(\mathrm{M}+\mathrm{H})^{+} \cdot[\alpha]_{\mathrm{D}}^{25}+14.0^{\circ}\left(c 1.00, \mathrm{CHCl}_{3}\right)$.

\section{Fmoc-Val-Asp(OtBu)-D-Leu-OBzl (19)}

To a solution of $17(6.14 \mathrm{~g}, 10 \mathrm{mmol})$ in DMF $(100 \mathrm{ml})$ was added $\mathrm{NEt}_{2} \mathrm{H}(10 \mathrm{ml})$ and the solution was stirred at room temperature for 3 hourrs. Removal of the solvent gave the crude product (18) which was used in the next reaction without further purification.

To a solution of $18(10 \mathrm{mmol})$, Fmoc-Val $(3.39 \mathrm{~g}$, $10 \mathrm{mmol})$ and $\mathrm{HOBt} \cdot \mathrm{H}_{2} \mathrm{O}(4.53 \mathrm{~g}, 10 \mathrm{mmol})$ in $\mathrm{DMF}$ $(70 \mathrm{ml})$ was added WSCI $\cdot \mathrm{HCl}(1.92 \mathrm{~g}, 10 \mathrm{mmol})$ at an ice cooled temperature. This reaction mixture was stirred at this temperature for 2 hours and then at room temperature overnight. After removal of solvent, the residue was taken up to AcOEt and 10\% aq. citric acid. The separated organic layer was rinsed with $\mathrm{H}_{2} \mathrm{O}, 5 \%$ aq. $\mathrm{NaHCO}_{3}$ and $\mathrm{H}_{2} \mathrm{O}$, and then dried $\left(\mathrm{Na}_{2} \mathrm{SO}_{4}\right)$. After removal of the solvent, the crude product was purified by recrystallization from $\mathrm{CHCl}_{3}-\mathrm{Et}_{2} \mathrm{O}$ to yield the product $(6.19 \mathrm{~g}, 87 \%)$. MP $160 \sim 162^{\circ} \mathrm{C}$. ESI-MS $\mathrm{m} / \mathrm{z}$ $714(\mathrm{M}+\mathrm{H})^{+} \cdot[\alpha]_{\mathrm{D}}^{25}-7.02^{\circ}\left(c 1.00, \mathrm{CHCl}_{3}\right)$.

\section{Fmoc-D-Leu-Val-Asp(OtBu)-D-Leu-OBzl (21)}

To a solution of $19(19.0 \mathrm{~g}, 26.5 \mathrm{mmol})$ in $\mathrm{DMF}$ $(265 \mathrm{ml})$ was added $\mathrm{NEt}_{2} \mathrm{H}(26.5 \mathrm{ml})$ and the solution was stirred at room temperature for 1 hour. After removal of the solvent, the residue was dissolved in AcOEt and rinsed with $\mathrm{H}_{2} \mathrm{O}$ twice, and then dried $\left(\mathrm{Na}_{2} \mathrm{SO}_{4}\right)$. After removal of the solvent, the crude product was purified by chromatography on silica gel $(70 \mathrm{~g})$, eluting with $\mathrm{CHCl}_{3}: \mathrm{MeOH}=200: 0 \sim 10$, to yield the product $(\mathbf{2 0})$ $(9.06 \mathrm{~g}, 69 \%)$.

To a solution of $\mathbf{2 0}(8.00 \mathrm{~g}, 16.3 \mathrm{mmol})$, Fmoc-D-Leu $(6.33 \mathrm{~g}, 17.9 \mathrm{mmol}, 1.1 \mathrm{eq})$ and HOBt $(2.42 \mathrm{~g}, 17.9 \mathrm{mmol}$, $1.1 \mathrm{eq})$ in $\mathrm{CH}_{2} \mathrm{Cl}_{2}(65 \mathrm{ml})$ was added WSCI$\cdot \mathrm{HCl}(3.43 \mathrm{~g}$, $17.9 \mathrm{mmol}, 1.1 \mathrm{eq})$ at an ice cooled temperature. This reaction mixture was stirred at this temperature for 2 hours and then at room temperature overnight. After removal of solvent, the residue was taken up to $\mathrm{CHCl}_{3}$ and $10 \%$ aq. citric acid. The separated organic layer was rinsed with $\mathrm{H}_{2} \mathrm{O}, 5 \%$ aq. $\mathrm{NaHCO}_{3}$ and $\mathrm{H}_{2} \mathrm{O}$, and then dried $\left(\mathrm{Na}_{2} \mathrm{SO}_{4}\right)$. After removal of the solvent, the crude product was purified by chromatography on silica gel (100 g), eluting with $\mathrm{CHCl}_{3}: \mathrm{MeOH}=200: 0 \sim 5$, to yield the product $(11.7 \mathrm{~g}, 87 \%)$. MP $178 \sim 179^{\circ} \mathrm{C}$. ESI-MS $m / z$ $827(\mathrm{M}+\mathrm{H})^{+} \cdot[\alpha]_{\mathrm{D}}^{26}+21.2^{\circ}\left(c 1.05, \mathrm{CHCl}_{3}\right)$.

Fmoc-Leu-D-Leu-Val-Asp(OtBu)-D-Leu-OBzl (23)

A solution of $21(11.5 \mathrm{~g}, 13.9 \mathrm{mmol})$ in $20 \%$ piperidine in DMF $(70 \mathrm{ml})$ was stirred at room temperature for 1 hour. After removal of the solvent, the crude product was purified by chromatography on silica gel $(80 \mathrm{~g})$, eluting with $\mathrm{CHCl}_{3}: \mathrm{MeOH}=200: 0 \sim 10$, to yield the product (22) (8.41 g, quant.).

To a solution of $22(8.41 \mathrm{~g}, 13.9 \mathrm{mmol})$, Fmoc-Leu 
$(5.40 \mathrm{~g}, 15.3 \mathrm{mmol}, 1.1 \mathrm{eq})$ and HOBt $(2.07 \mathrm{~g}, 15.3 \mathrm{mmol}$, $1.1 \mathrm{eq})$ in $\mathrm{CH}_{2} \mathrm{Cl}_{2}(60 \mathrm{ml})$ was added $\mathrm{WSCl} \cdot \mathrm{HCl}(2.93 \mathrm{~g}$, $15.3 \mathrm{mmol}, 1.1 \mathrm{eq})$ at an ice cooled temperature. This reaction mixture was stirred at this temperature for 2 hours and then at room temperature overnight. After removal of solvent, the residue was taken up to AcOEt and $10 \%$ aq. citric acid. The separated organic layer was rinsed with $\mathrm{H}_{2} \mathrm{O}, 5 \%$ aq. $\mathrm{NaHCO}_{3}$ and $\mathrm{H}_{2} \mathrm{O}$, and then dried $\left(\mathrm{Na}_{2} \mathrm{SO}_{4}\right)$. After removal of the solvent, the crude product was purified by chromatography on silica gel $(100 \mathrm{~g})$, eluting with $\mathrm{CHCl}_{3}: \mathrm{MeOH}=200: 0 \sim 5$, to yield the product which was solidified from $\mathrm{CHCl}_{3}-\mathrm{Et}_{2} \mathrm{O}$ $(10.5 \mathrm{~g}, 80 \%)$.

MP $181 \sim 182^{\circ} \mathrm{C}$. ESI-MS $m / z 940(\mathrm{M}+\mathrm{H})^{+} \cdot[\alpha]_{\mathrm{D}}^{24}$ $+48.9^{\circ}\left(c 1.01, \mathrm{CHCl}_{3}\right)$.

Fmoc-Gln(trt)-Leu-D-Leu-Val-Asp(OtBu)-D-LeuOBzl (25)

A solution of $23(4.00 \mathrm{~g}, 4.25 \mathrm{mmol})$ in $20 \%$ piperidine in DMF (20 ml) was stirred at room temperature for 20 minutes. After removal of the solvent, the crude product was purified by chromatography on silica gel $(40 \mathrm{~g})$, eluting with $\mathrm{CHCl}_{3}: \mathrm{MeOH}=200: 0 \sim 5$, to yield the product $(2.94 \mathrm{~g}, 96 \%)$.

To a solution of this amine $(2.94 \mathrm{~g}, 4.09 \mathrm{mmol})$, Fmoc-Gln(Trt) $(2.75 \mathrm{~g}, 4.50 \mathrm{mmol}, 1.1 \mathrm{eq})$ and $\mathrm{HOBt}$ $(0.61 \mathrm{~g}, 4.5 \mathrm{mmol}, 1.1 \mathrm{eq})$ in $\mathrm{CH}_{2} \mathrm{Cl}_{2}(20 \mathrm{ml})$ was added $\mathrm{WSCl} \cdot \mathrm{HCl}(0.86 \mathrm{~g}, 4.5 \mathrm{mmol}, 1.1 \mathrm{eq})$ at an ice cooled temperature. This reaction mixture was stirred at this temperature for 1.5 hours and then at room temperature overnight. After removal of solvent, the residue was taken up to AcOEt and 10\% aq. citric acid. The separated organic layer was rinsed with $\mathrm{H}_{2} \mathrm{O}, 5 \%$ aq. $\mathrm{NaHCO}_{3}$ and $\mathrm{H}_{2} \mathrm{O}$, and then dried $\left(\mathrm{Na}_{2} \mathrm{SO}_{4}\right)$. After removal of the solvent, the crude product was purified by chromatography on silica gel (70 g), eluting with $\mathrm{CHCl}_{3}$ : $\mathrm{MeOH}=200: 0 \sim 5$, to yield the product which was solidified from $\mathrm{CHCl}_{3}-\mathrm{Et}_{2} \mathrm{O}(5.11 \mathrm{~g}, 95 \%)$.

MP $194 \sim 195^{\circ} \mathrm{C}$. ESI-MS $m / z 1310(\mathrm{M}+\mathrm{H})^{+} \cdot[\alpha]_{\mathrm{D}}^{25}$ $+42.4^{\circ}\left(c 1.02, \mathrm{CHCl}_{3}\right)$.

\section{Fmoc-Gln(trt)-Leu-D-Leu-Val-Asp(OtBu)-D-Leu-OH} (26)

A suspension of $25(5.00 \mathrm{~g}, 3.81 \mathrm{mmol})$ and $5 \% \mathrm{Pd}-\mathrm{C}$ $(0.80 \mathrm{~g})$ in $\mathrm{MeOH}(120 \mathrm{ml})$ was reacted under $\mathrm{a} \mathrm{H}_{2}$ atmosphere $\left(2 \mathrm{~kg} / \mathrm{cm}^{2}\right)$ for 1.5 hours at room temperature. After filtration and evaporation, the crude product was purified by chromatography on silica gel $(50 \mathrm{~g})$, eluting with $\mathrm{CHCl}_{3}: \mathrm{MeOH}=200: 0 \sim 15$, to yield the product which was solidified from $\mathrm{CHCl}_{3}-\mathrm{Et}_{2} \mathrm{O}(3.88 \mathrm{~g}$,
$83 \%)$.

(R)-Benzyl 3-Hydroxy-13-methyltetradecanoate (27a)

To a solution of $\mathbf{1 1}(5.00 \mathrm{~g}, 19.3 \mathrm{mmol})$ and $\mathrm{Et}_{3} \mathrm{~N}$ $(2.7 \mathrm{ml}, 19 \mathrm{mmol})$ in DMF $(50 \mathrm{ml})$ was added benzyl bromide $(2.3 \mathrm{ml}, 19 \mathrm{mmol})$ at room temperature. This reaction mixture was stirred at room temperature overnight. After removal of the solvent, the residue was taken up to AcOEt and $\mathrm{H}_{2} \mathrm{O}$. The separated organic layer was rinsed with $\mathrm{H}_{2} \mathrm{O}$ twice and then dried $\left(\mathrm{Na}_{2} \mathrm{SO}_{4}\right)$. After removal of the solvent, the crude product was purified by chromatography on silica gel (30 g), eluting with $\mathrm{CHCl}_{3}: \mathrm{MeOH}=200: 0 \sim 15$, to yield the product which was recrystallized from $n$-hexane $(3.33 \mathrm{~g}, 49 \%)$ and to recover the starting material $2.33 \mathrm{~g}$ $(47 \%)$. MP $30^{\circ} \mathrm{C}$. $[\alpha]_{\mathrm{D}}^{25}-14.5^{\circ}$ (c $\left.1.00, \mathrm{CHCl}_{3}\right) .{ }^{1} \mathrm{H}$ NMR $\left(400 \mathrm{MHz}, \mathrm{CDCl}_{3}\right) \delta 7.31 \sim 7.41(5 \mathrm{H}, \mathrm{m}, \mathrm{Ar}-H)$, $5.15\left(2 \mathrm{H}, \mathrm{s}, \mathrm{CH}_{2} \mathrm{Ph}\right), 3.98 \sim 4.06(1 \mathrm{H}, \mathrm{m}, \mathrm{CHOH}), 2.85$ $(1 \mathrm{H}, \mathrm{d}, J=3.9 \mathrm{~Hz}, \mathrm{CHOH}), 2.56(1 \mathrm{H}, \mathrm{dd}, J=3.2,17 \mathrm{~Hz}$, $\left.\mathrm{CH}_{2} \mathrm{CO}_{2}\right), 2.46\left(1 \mathrm{H}, \mathrm{dd}, J=9.1,16 \mathrm{~Hz}, \mathrm{CH}_{2} \mathrm{CO}_{2}\right)$, $1.47 \sim 1.57\left(2 \mathrm{H}, \mathrm{m}, \mathrm{CH}_{2}\right), 1.37 \sim 1.47\left(2 \mathrm{H}, \mathrm{m}, \mathrm{CH}{ }_{2}\right.$, $1.19 \sim 1.37\left(13 \mathrm{H}, \mathrm{m}, \mathrm{CH}_{2}\right), 1.11 \sim 1.19\left(2 \mathrm{H}, \mathrm{m}, \mathrm{CH}_{2}\right)$, $0.86\left(6 \mathrm{H}, \mathrm{d}, J=6.3 \mathrm{~Hz}, \mathrm{CH}\left(\mathrm{CH}_{3}\right)_{2}\right)$. Anal Calcd for $\mathrm{C}_{22} \mathrm{H}_{36} \mathrm{O}_{3}$ : C 75.8, $\mathrm{H}$ 10.4; Found C 75.9, H 10.5 .

(S)-Benzyl 3-Hydroxy-13-methyltetradecanoate (27b) $\mathrm{MP} 28 \sim 29^{\circ} \mathrm{C} .[\alpha]_{\mathrm{D}}^{25}+14.2^{\circ}\left(c 1.00, \mathrm{CHCl}_{3}\right) .{ }^{1} \mathrm{H} \mathrm{NMR}$ $\left(400 \mathrm{MHz}, \mathrm{CDCl}_{3}\right) \delta 7.30 \sim 7.41(5 \mathrm{H}, \mathrm{m}, \mathrm{Ar}-H), 5.15$ $\left(2 \mathrm{H}, \mathrm{s}, \mathrm{CH}_{2} \mathrm{Ph}\right), 4.02(1 \mathrm{H}$, br s, $\mathrm{CHOH}), 2.86(1 \mathrm{H}, \mathrm{d}$, $J=3.4 \mathrm{~Hz}, \quad \mathrm{CHOH}), 2.56(1 \mathrm{H}, \mathrm{dd}, J=3.4,17 \mathrm{~Hz}$, $\left.\mathrm{CH}_{2} \mathrm{CO}_{2}\right), 2.46\left(1 \mathrm{H}, \mathrm{dd}, J=8.8,17 \mathrm{~Hz}, \mathrm{CH}_{2} \mathrm{CO}_{2}\right)$, $1.48 \sim 1.57\left(2 \mathrm{H}, \mathrm{m}, \mathrm{CH}_{2}\right), 1.37 \sim 1.47\left(2 \mathrm{H}, \mathrm{m}, \mathrm{CH}_{2}\right)$, $1.19 \sim 1.36\left(13 \mathrm{H}, \mathrm{m}, \mathrm{CH}_{2}\right), 1.10 \sim 1.18\left(2 \mathrm{H}, \mathrm{m}, \mathrm{CH}_{2}\right)$, $0.86\left(6 \mathrm{H}, \mathrm{d}, J=6.3 \mathrm{~Hz}, \mathrm{CH}\left(\mathrm{CH}_{3}\right)_{2}\right)$. Anal Calcd for $\mathrm{C}_{22} \mathrm{H}_{36} \mathrm{O}_{3}$ : C 75.8, H 10.4; Found C 75.9, H 10.2.

Benzyl 13-Methyl-( $R$ )-3-(Fmoc-Ile-O)-tetradecanoate $\underline{(28 a)}$

To a solution of $27 \mathrm{a}(2.33 \mathrm{~g}, 6.69 \mathrm{mmol})$, Fmoc-Ile $(2.60 \mathrm{~g}, 7.35 \mathrm{mmol}, 1.1 \mathrm{eq})$ and DMAP $(57 \mathrm{mg}, 0.47$ mmol, 0.07 eq $)$ in $\mathrm{CH}_{2} \mathrm{Cl}_{2}(40 \mathrm{ml})$ was added DCC $(2.07 \mathrm{~g}$, $10.0 \mathrm{mmol}, 1.5 \mathrm{eq})$ at an ice cooled temperature This was stirred at this temperature for 3 hours and the at room temperature overnight. After filtration and evaporation, the residue was taken up to AcOEt and $10 \%$ aq. citric acid. The separated organic layer was rinsed with $\mathrm{H}_{2} \mathrm{O}$, $5 \%$ aq. $\mathrm{NaHCO}_{3}$ and $\mathrm{H}_{2} \mathrm{O}$, and then dried $\left(\mathrm{Na}_{2} \mathrm{SO}_{4}\right)$. After removal of the solvent, the crude product was purified by chromatography on silica gel $(70 \mathrm{~g})$, eluting with Hex: AcOEt $=200: 0 \sim 30$, to yield the product 
(4.57g, quant.). $[\alpha]_{\mathrm{D}}^{25}-0.35^{\circ}\left(c 1.00, \mathrm{CHCl}_{3}\right)$. ESI-MS $m / z 684(\mathrm{M}+\mathrm{H})^{+}$.

Benzyl 13-Methyl-(S)-3-(Fmoc-Ile-O)-tetradecanoate (28b)

$[\alpha]_{\mathrm{D}}^{25}+2.82^{\circ}\left(c 1.00, \mathrm{CHCl}_{3}\right)$. ESI-MS $m / z 684$ $(\mathrm{M}+\mathrm{H})^{+}$

Benzyl 13-Methyl-( $R)-3-($ Fmoc-Gln(Trt)-Leu-D-LeuVal-Asp(OtBu)-D-Leu-O)-tetradecanoate (29a)

A solution of benzyl $28 \mathrm{a}(0.68 \mathrm{~g}, 0.99 \mathrm{mmol})$ and $\mathrm{NEt}_{2} \mathrm{H}(1 \mathrm{ml})$ in DMF $(10 \mathrm{ml})$ was stirred at room temperature for 1 hour. After removal of the solvent, the crude product was purified by chromatography on silica gel $(25 \mathrm{~g})$, eluting with $\mathrm{CHCl}_{3}: \mathrm{MeOH}=100: 0 \sim 3$, to yield the product $(0.44 \mathrm{~g}, 90 \%)$.

To a solution of this amine $(0.44 \mathrm{~g}, 0.90 \mathrm{mmol})$, FmocGln(trt)-Leu-D-Leu-Val-Asp(OtBu)-D-Leu-OH (1.10 g, $0.90 \mathrm{mmol})$ and $\mathrm{HOBt}(0.12 \mathrm{~g}, 0.90 \mathrm{mmol})$ in $\mathrm{CH}_{2} \mathrm{Cl}_{2}$ $(20 \mathrm{ml})$ was added $\mathrm{WSCl} \cdot \mathrm{HCl}(0.17 \mathrm{~g}, 0.90 \mathrm{mmol})$ at an ice cooled temperature. This was stirred at this temperature for 2 hours and then at room temperature overnight. After removal of the solvent, the residue was taken up to AcOEt and 10\% aq. citric acid. The separated organic layer was rinsed with $\mathrm{H}_{2} \mathrm{O}, 5 \%$ aq. $\mathrm{NaHCO}_{3}$ and $\mathrm{H}_{2} \mathrm{O}$, and then dried $\left(\mathrm{Na}_{2} \mathrm{SO}_{4}\right)$. After removal of the solvent, the crude product was purified by chromatography on silica gel $(30 \mathrm{~g})$, eluting with $\mathrm{CHCl}_{3}$ : $\mathrm{MeOH}=200: 0 \sim 3$, to yield the product which was solidified from $\mathrm{Et}_{2} \mathrm{O}(1.48 \mathrm{~g}, 99 \%) .[\alpha]_{\mathrm{D}}^{25}+38.2^{\circ}(c$ $1.02, \mathrm{CHCl}_{3}$ ).

$[\alpha]_{\mathrm{D}}^{24}+38.2^{\circ}\left(c 1.02, \mathrm{CHCl}_{3}\right)$. ESI-MS $m / z 1663$ $(\mathrm{M}+\mathrm{H})^{+}$

Benzyl 13-Methyl-(S)-3-(Fmoc-Gln(Trt)-Leu-D-LeuVal-Asp(OtBu)-D-Leu-O)-tetradecanoate (29b)

$[\alpha]_{\mathrm{D}}^{26}+41.6^{\circ}$ (c $1.00, \mathrm{CHCl}_{3}$ ). ESI-MS $m / z 1663$ $(\mathrm{M}+\mathrm{H})^{+}$

Cyclo\{13-methyl- $(R)-3-[\mathrm{G} \ln (\mathrm{Trt})-\mathrm{Leu}-\mathrm{D}-\mathrm{Leu}-\mathrm{Val}$ Asp(OtBu)-D-Leu-O]-tetradecanoate (30a)

A suspension of $29 \mathrm{a}(2.50 \mathrm{~g}, 1.50 \mathrm{mmol})$ and $5 \% \mathrm{Pd}-\mathrm{C}$ $(2.50 \mathrm{~g})$ in $\mathrm{MeOH}(100 \mathrm{ml})$ was reacted under a $\mathrm{H}_{2}$ atmosphere $\left(2 \mathrm{~kg} / \mathrm{cm}^{2}\right)$ for 40 minutes at room temperature. After filtration and evaporation, the crude product was purified by chromatography on silica gel (60 g), eluting with $\mathrm{CHCl}_{3}: \mathrm{MeOH}=200: 0 \sim 6$, to yield the product $(1.27 \mathrm{~g}, 54 \%)$.

A solution of this acid $(0.60 \mathrm{~g}, 0.38 \mathrm{mmol})$ in $20 \%$ piperidine in DMF $(20 \mathrm{ml})$ was stirred at room tem- perature for 1 hour. After removal of the solvent, the crude product was purified by chromatography on silica gel $(60 \mathrm{~g})$, eluting with $\mathrm{CHCl}_{3}: \mathrm{MeOH}=200: 0 \sim 20$, to yield the product $(0.44 \mathrm{~g}, 85 \%)$.

To a solution of this depsipeptide $(0.30 \mathrm{~g}, 0.22 \mathrm{mmol})$ in DMF (300 ml) was added DIPEA $(0.15 \mathrm{ml}, 0.89 \mathrm{mmol}$, $4 \mathrm{eq}$ ), HOAt (91 mg, $0.67 \mathrm{mmol}, 3 \mathrm{eq})$ and HATU $(0.25 \mathrm{~g}$, $0.67 \mathrm{mmol}, 3 \mathrm{eq}$ ) at room temperature. This resulting yellow solution was stirred at room temperature overnight. After removal of the solvent, the residue was taken up to AcOEt and $5 \%$ aq. $\mathrm{KHSO}_{4}$. The separated organic layer was rinsed with $\mathrm{H}_{2} \mathrm{O}$ and brine, and then dried $\left(\mathrm{Na}_{2} \mathrm{SO}_{4}\right)$. After removal of the solvent, the crude product was purified by chromatography on silica gel (5g), eluting with $\mathrm{CHCl}_{3}:$ AcOEt $=50: 0 \sim 40$, to yield the product $(0.29 \mathrm{~g}, 95 \%)$.

$[\alpha]_{\mathrm{D}}^{26}+30.0^{\circ}\left(c \quad 0.40, \mathrm{CHCl}_{3}\right)$. ESI-MS $m / z 1333$ $(\mathrm{M}+\mathrm{H})^{+}$

Cyclo\{13-methyl-(S)-3-[Gln(Trt)-Leu-D-Leu-Va1Asp(OtBu)-D-Leu-O]-tetradecanoate 3 (30b)

$\left.[\alpha]_{\mathrm{D}}^{26}+42.0^{\circ}(c) 1.00, \mathrm{CHCl}_{3}\right)$. ESI-MS $m / z 1333$ $(\mathrm{M}+\mathrm{H})^{+}$.

Cyclo\{13-methyl- $(R)-3-[$ GIn-Leu-D-Leu-Val-AspD-Leu-O]-tetradecanoate $\}$ (1a)

A solution of cyclo\{13-methyl-( $R)-3-[\mathrm{G} \ln (\mathrm{Trt})-\mathrm{Leu}-\mathrm{D}-$ Leu-Val-Asp(OtBu)-D-Leu-O]-tetradecanoate (170 mg, $0.13 \mathrm{mmol})$ in TFA $(5 \mathrm{ml})$ was stirred at room temperature for $30 \mathrm{~min}$. After removal of the solvent, the residue was purified by chromatography on silica gel (5 g), eluting with $\mathrm{CHCl}_{3}: \mathrm{MeOH}=50: 0 \sim 7$, to yield the product $(125 \mathrm{mg}, 95 \%)$.

$[\alpha]_{\mathrm{D}}^{26}-9.86^{\circ}\left(c 0.40, \mathrm{CH}_{3} \mathrm{OH}\right) \cdot\left[\right.$ lit. $^{1)}[\alpha]_{\mathrm{D}}^{26}-11.2^{\circ}(c$ $0.414, \mathrm{CH}_{3} \mathrm{OH}$ )] High-resolution FAB-MS (positive) $\mathrm{m} / \mathrm{z}$ 1057.6923 [calcd for $\mathrm{C}_{53} \mathrm{H}_{94} \mathrm{~N}_{8} \mathrm{O}_{12} \mathrm{Na}(\mathrm{M}+\mathrm{Na})^{+}$; $1057.6889]$

Cyclo $\{13-$ methyl- $(S)-3-[$ Gln-Leu-D-Leu-Val-AspD-Leu-O]-tetradecanoate $(\mathbf{1 b})$

$[\alpha]_{\mathrm{D}}^{26}-19.0^{\circ}$ (c $\left.0.50, \mathrm{CH}_{3} \mathrm{OH}\right)$. High-resolution FAB-MS (positive) $m / z \quad 1057.6960$ [calcd for $\mathrm{C}_{53} \mathrm{H}_{94}$ $\left.\mathrm{N}_{8} \mathrm{O}_{12} \mathrm{Na}(\mathrm{M}+\mathrm{Na})^{+} ; 1057.6889\right]$.

\section{References}

1) Hiramoto, S; N. Kinoshita, S. Hatanaka \& H. Seto: Stimulation of apolipoprotein $\mathrm{E}$ secretion in human hepatoma hep $\mathrm{G} 2$ cells by a cyclic acylpeptide, N-4909. J. Antibiotics 49: 949 952, 1996

2) Yamada, N.; I. Inoue, M. Kawamura, K. Harada, Y. Watanabe, H. Shimano, T. Gotohda, M. Shimada, K. 
Kohzaki, T. Tsukada, M. Shiomi, Y. Watanabe \& Y. YAZAKI: Apolipoprotein $E$ prevents the progression of atherosclerosis in Watanabe heritable hyperlipidemic rabbits. J. Clin. Invest. 89: 706 711, 1992

3) Mahley, R. W.; K. H. Weisgrauber, M. M. Hussain, B. Greenman, M. Fisher, T. Vogal \& M. Gorecki: Intravenous infusion of apolipoprotein $\mathrm{E}$ accelerates clearance of plasma lipoprotein in rabbits. J. Clin. Invest. 83: $2125 \sim 2130,1989$

4) Yamada, N.; H. Shimano, H. Mokuno, S. Ishibashi, T. Gotohda, M. Kawakami, Y. Watanabe, Y. Akanuma, T. Murase \& F. TAKAKU: Increased clearance of plasma cholesterol after injection of apolipoprotein $\mathrm{E}$ into Watanabe heritable hyperlipidemic rabbits. Proc. Natl. Acad. Sci. U.S.A. 86: 665 669, 1989
5) Hasumi, K.; K. Takizawa, F. Takahashi, J. K. Park \& A. ENDO: Inhibition of acyl-CoA: Cholesterol acyltransferase by isohalobacillin, a complex of novel cyclic acylpeptides produced by Bacillus sp. A1238. J. Antibiotics 48: $1419 \sim 1424,1995$

6) Sugai, T.; H. Ritzen \& C.-H. Wong: Towards the chemoenzymatic synthesis of lipid A. Tetrahedron: Asymmetry 4: 1051 1508, 1993

7) Harumi, K.; M. Miura \& K. Orito: A short route to dihydrocapsaicinoids. Synthesis: $864 \sim 866,1985$

8) TAtsuyoshI, I; K. WADA: Total synthesis of ( \pm )diplodialide-A. J. C. S. Perkin I, 323 327, 1979 